Атаманчук 3. А., кандидат економічних наук, доцент, доцент кафедри міжнародних економічних відносин, Донецький національний університет імені Василя Стуса, Україна

ORCID: 0000-0002-6139-1653

z.atamanchuk@donnu.edu.ua

Неголюк Ю. В., здобувач, Донецький національний університет імені Василя Стуса, Україна ORCID: 0000-0001-9607-225X neholiuk.i@donnu.edu.ua

\title{
ІНВЕСТИЦЙНЕ ЗАБЕЗПЕЧЕННЯ «ЗЕЛЕНОӤ» ЕКОНОМІКИ ЯК ПРІОРИТЕТНИЙ НАПРЯМ РОЗВИТКУ ДЕРЖАВИ НА ЗАСАДАХ СТАЛОГО РОЗВИТКУ
}

Визначено ключові пріоритети розвитку «зеленої» економіки; вивчено стан інвестиційного забезпечення «зеленого» сектору в Украйні та світі, світовий досвід залучення «зелених» технологій» в економіку; обтрунтовано перешкоди, які стримують збільшення інвестування у «зелений» сектор економіки Украӥни та ключові пріоритети розвитку сектору на основі відповідних програм; сформовано подальші орієнтири розвитку «зеленої» економіки шляхом залучення інвестицій, на засадах сталого виробництва та споживання, ефективного використання ресурсів, а також сприяння діяльності бізнесу в спосіб ресурсо- та енергоефективного, екологічно безпечного виробництва. Запропоновано модель переходу Украйни до «зеленої» економіки; обтрунтовано, щз за умов наслідування досвіду провідних країн, чіткого державного регулювання та підтримки, якісного забезпечення інвестиціями та чітких законодавчих $i$ правових норм, дана модель переходу та побудови нової економіки може призвести до стрімкого сочіально-економічного поступу Украӥни.

Ключові слова: «зелена» економіка, інвестиції, інвестиційна привабливість, інновачійне забезпечення, сталий розвиток.

Кількість рис.- 2, табл. - 2 .

Постановка проблеми. В умовах швидкого зростання та розширення промислових зон, а також розбудови індустріальних міст та кооперації в епоху глобалізаційних процесів, населення землі зазнає значних змін, що проявляються кліматичними коливаннями, забрудненням територій та виснаженням природних ресурсів. Для підтримання балансу та стабілізації ситуації, уряди країн світу намагаються шукати шляхи поновлення або заміни ресурсів $з$ метою відкриття нових джерел енергії. Розвинені країни світу переходять до все більш масштабного використання «зелених» технологій, для розширення своїх можливостей та забезпечення населення країн вищим та безпечним рівнем життя. Зважаючи на світові тенденції, підтримка та стимулювання розвитку «зеленої» економіки сприяє покращенню соціально-економічних показників розвитку держави. Надання підприємствам підтримки у переході на новий рівень виробництва шляхом залучення нових 
еко-технологій або нових джерел енергії, забезпечує підвищення прибутку суб'єктів господарювання за економії ресурсів. Зважаючи на позитивні показники впровадження таких тенденцій, Україні слід переглянути державну політику стосовно даного виду діяльності підприємств та забезпечити достатній рівень інвестицій.

Аналіз останніх досліджень. Питання інвестиційної привабливості сектору «зеленої» економіки розглядалося як іноземними, так і українськими вченими. Серед них: В. Базилевич, О. Веклич, О. Вишнецька, Л. Мельник, І. Петренко, Підвисоцький, А. Фролов та інші. Однак, зважаючи на постійні зміни в світовому економічному просторі, пошук нових технологій та удосконалення бізнес-середовища, проблемні питання залучення інвестицій у цей сектор потребують подальших наукових досліджень.

Метою дослідження $€$ вивчення стану інвестиційного забезпечення «зеленого» сектору в Україні та світі 3 метою порівняння основних показників та формування подальших орієнтирів розвитку «зеленої» економіки на засадах залучення інвестицій.

\section{Завдання:}

визначення підходів до тлумачення терміну «зелена» економіка;

вивчення світового досвіду залучення «зелених» технологій в економіки країн світу; обгрунтування недоліків та перешкод у розвитку «зеленої» економіки;

окреслення основних переваг від інвестування у «зелений» сектор;

надання рекомендацій щодо стимулювання розвитку «зелених» технологій для покращення інвестиційного клімату в досліджуваній площині.

Виклад основного матеріалу. Сучасне суспільство перебуває на етапі перетворень, які відбуваються під впливом кліматичних змін, виснаження природних ресурсів та розвитку нових джерел енергії. За словами Генерального секретаря Організація Об'єднаних Націй $(\mathrm{OOH})$ Пан Гі Муна: «За останне сторіччя ми були свідками трьох економічних перетворень. Спочатку відбулася промислова революція, потім - технологічна революція, за якою настала сучасна ера глобалізації. Зараз ми стоїмо на порозі нових великих змін - на порозі епохи «зеленої економіки» [1].

Вперше термін «зелена» економіка був наведений у публікації «Blueprint for a Green economy» [2], яка була присвячена економічному обгрунтуванню концепції сталого розвитку. На противагу «зеленій», розглядається «коричнева» економіка. Для переходу від коричневої до зеленої економіки потрібні трильйони доларів у вигляді інвестицій. Пан Гі Мун закликав інвесторів, банкірів та інших фінансистів збільшити фінансові потоки в низьковуглецеву енергетику і в розвиток екологічно стійких інфраструктур, адже тільки таким чином можна побудувати кращий, безпечніший світ для нинішнього і майбутніх поколінь [3].

Питання доцільності та ефективності інвестування у дану сферу розглядалися Радою Організації Об’єднаних Націй $(\mathrm{OOH})$ та іншими світовими організаціями, згідно 3 рішеннями яких було визначено сектор «зеленої» економіки одним із пріоритетних у розвитку держав світу. Згідно з доповідями організацій, світові тенденції до підвищення інвестицій в «зелену» економіку призводять до покращення економічних, соціальних та екологічних показників, які, водночас, сприяють підвищенню рівня розвитку держави та рівня благополуччя суспільства в цілому.

«Зелена» економіка є базисом реалізації концепції сталого розвитку на основі більш ефективного ресурсо- та енергоспоживання, зниження рівнів викидів СО2, зменшення шкідливого впливу на довкілля та розвитку соціально інтегрованого суспільства. Але «озеленення» економіки вимагає переформатування поточних і майбутніх інвестицій, додаткових витрат за межами звичайного підходу. 
Сьогодні одним із основних завдань українського уряду є забезпечення інструментів для сталого розвитку та покращення інвестиційного клімату в Україні. 3 метою контролю за досягненням цілей була розроблена Стратегія сталого розвитку, метою якої $\epsilon$ впровадження в Україні європейських стандартів життя та вихід України на провідні позиції у світі. Задля досягнення бажаних результатів, державі слід створювати сприятливі умови для розвитку бізнесу та стимулювати підприємництво, досягати максимальних результатів без шкоди для суспільства та мінімізації використання ресурсів. Для цього, передусім, необхідно відновити макроекономічну стабільність, забезпечити стійке зростання економіки екологічно невиснажливим способом. Це призведе до покращення стандартів життя, переходу країни до більш ефективного використання технологій та забезпечить економічне зростання.

Світовий досвід залучення «зелених» технологій в економіку свідчить про покращення більшості економічних показників. Інвестування в захист навколишнього середовища та розробку стратегій пошуку нових джерел енергії стало одним із пріоритетних напрямків державної політики багатьох країн світу. Найбільший обсяг «зелених» інвестицій у рамках екологічно орієнтованих заходів, передбачених державними програмами з відновлення економіки, припадає на Китай (22 300 млн євро), Японію (12 300 млн євро), Республіку Корею (9 300 млн євро), Францію (5 700 млн євро), Данію (700 млн євро), Бельгію (118,8 млн євро) [4].

«Зелені» інвестиції можуть позитивно впливати на енергетичний баланс країни, підвищувати рівень енергоефективності економіки та конкурентоспроможності вітчизняної продукції на світових ринках, а також платоспроможності населення, зокрема за житловокомунальні послуги. Вони здатні створювати нові робочі місця та забезпечувати гідну заробітну плату працівникам. Прикладом виявлення ступеня «зеленості» світової економіки сьогодні є Глобальний індекс «зеленої» економіки - The Global Green Economy Index (GGEI), розроблений рейтинговим агентством Dual Citizen у 2010 році. Так, за рейтингом 2018 року, який відображає розвиток зеленої економіки у 130 країнах, лідируючі позиції займає Швеція. Україна ж посіла 120 місце, що свідчить про низький рівень інвестиційної привабливості, недостатній рівень державної підтримки та нестабільність економічних показників (табл. 1).

Таблиця 1 - Глобальний індекс «зеленої» економіки у 2018 році

\begin{tabular}{|c|l|l|}
\hline Рейтинг & \multicolumn{1}{|c|}{ Країна } & Індекс \\
\hline 1 & Швеція & 0,7608 \\
\hline 2 & Швейцарія & 0,7594 \\
\hline 3 & Ісландія & 0,7129 \\
\hline 4 & Норвегія & 0,7031 \\
\hline 5 & Фінляндія & 0,6997 \\
\hline 6 & Німеччина & 0,689 \\
\hline 7 & Данія & 0,68 \\
\hline 8 & Тайвань & 0,6669 \\
\hline 9 & Австрія & 0,6479 \\
\hline 10 & Франція & 0,6405 \\
\hline 120 & Україна & 0,3813 \\
\hline
\end{tabular}

Джерело: побудовано автором за [5]

Для підвищення рейтингової позиції та покращення показників, уряд України розробив стратегію екологізації підприємницької діяльності, яка сприяла залученню 
сучасних технологій, використанню поновлювальних джерел енергії, збільшенню кількості захисних споруд та забезпеченню пільгової системи для деяких підприємств.

Зважаючи на прагнення України стати рівноправним членом Європейського Союзу, сильним гравцем на світовому ринку, потрібно дотримуватися відповідних стандартів та намагатися забезпечити високі показники у даній сфері. Політика Європейського Союзу (СС) спрямована на розбудову «зеленої», «низьковуглецевої» економіки за рахунок зменшення викидів парникових газів та негативного впливу на довкілля. Це реалізується за допомогою як прямих, так і непрямих методів державного регулювання.

Перспективними напрямами інвестування у «зеленій» економіці розглядаються [2]: підвищення енергоефективності старих і нових будівель; виробництво еко товарів та послуг; перехід до альтернативних джерел енергії (вітер, сонце, біомаса, геотермальна енергія); підвищення довіри до збалансованого розвитку транспорту; стимулювання екологічної інфраструктури планети, включаючи питну воду, ліси, грунти, рифи; підтримка сталого сільського господарства, в тому числі органічного виробництва.

Згідно з доповіддю FTSE Russell70, «зелена» економіка сьогодні вартує стільки ж, скільки сектор викопного палива, але пропонує значні та «безпечні» інвестиційні можливості. У звіті зазначається, що на «зелену» економіку сьогодні припадає 6\% світового фондового ринку (близько 4 трлн дол. США), що залучені у проєкти «чистої» енергетики, енергоефективності, водопостачання, поводження 3 відходами тощо. Якщо ж стала економіка збереже свій поточний курс і тенденції розвитку, а також буде вкладено близько 90 трлн дол. США «зелених» інвестицій, то у 2030 році вона сформує приблизно $10 \%$ світової ринкової вартості [5]. Пріоритетними галузями, які зазнали змін під впливом «зелених» технологій $\epsilon$ енергетика та будівництво, запровадження енергозберігаючих технологій (рис. 1).

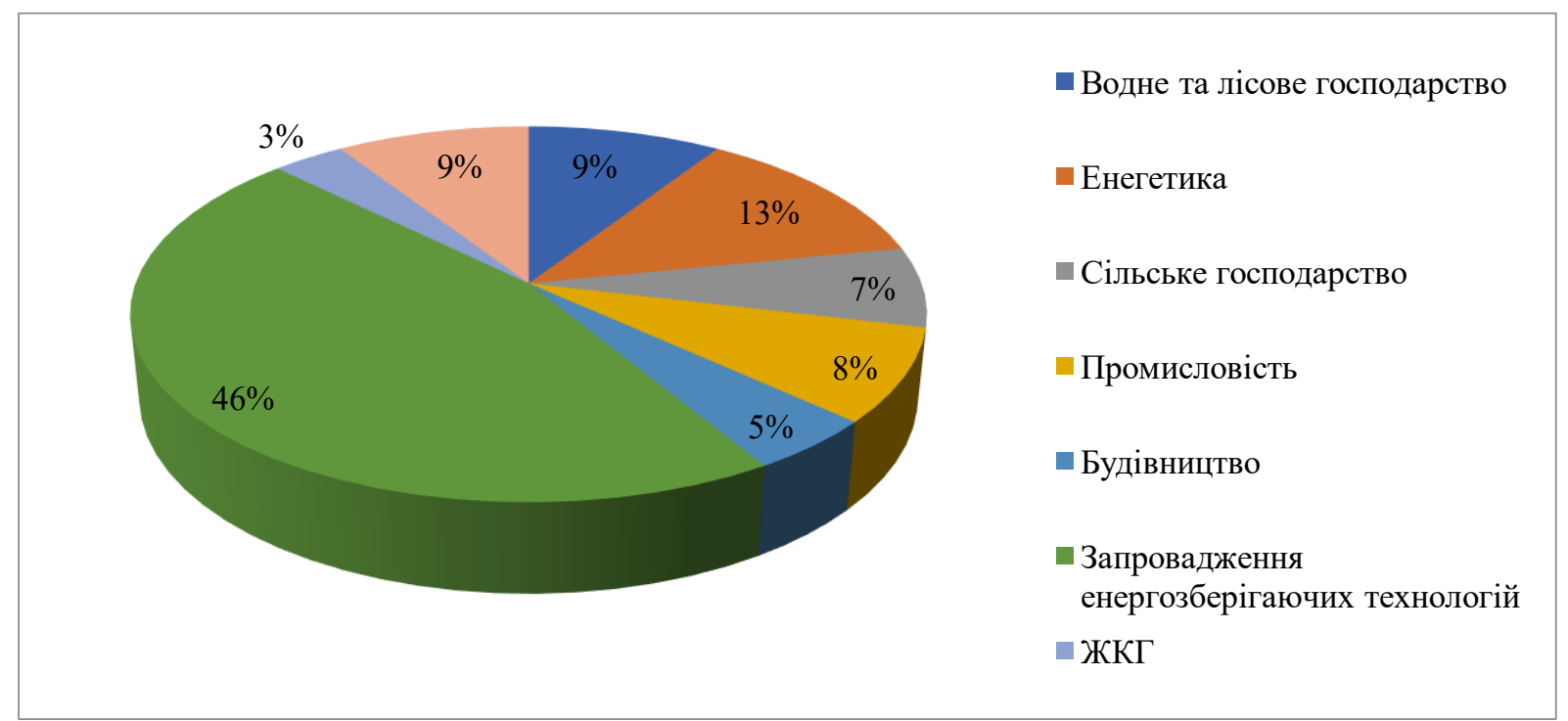

Рисунок 1. Відсоткове значення проникнення технологій «зеленої» економіки в різні Джерело: побудоване автором на основі [5] сектори

В Україні існує ряд перешкод, які стримують збільшення інвестування у «зелений» сектор економіки. Здебільшого інвестори турбуються про державну підтримку та повернення своїх коштів, а також ефективний правовий захист. Зважаючи на крайні 
тенденції, уряд України намагається вводити пільгові дотації та допомогу підприємствам, які використовують «зелені» технології у своїй роботі, але значні бюрократичні процедури нівелюють очікуваний ефект. На сьогодні основним завданням України $є$ перехід національної економіки до «зеленої» моделі розвитку на засадах сталого виробництва та споживання, ефективного використання ресурсів, а також сприяння діяльності бізнесу в спосіб ресурсо- та енергоефективного, екологічно безпечного виробництва.

За останні роки в Україні було схвалено низку заходів щодо переходу до «зеленої» економіки, серед яких: утворення Кабінетом Міністрів України Ради 3 питань торгівлі та сталого розвитку (Постанова КМУ від 13 червня 2018 року) та Координаційної ради 3 питань реалізації Національної стратегії управління відходами в Україні до 2030 року (Постанова КМУ від 25 квітня 2018 року); ухвалення Урядом України Концепції реформування системи державного нагляду (контролю) у сфері охорони навколишнього природного середовища (Постанова КМУ від 21 лютого 2018 року), а також Концепції створення загальнодержавної автоматизованої системи «Відкрите довкілля» (Розпорядження КМУ від 7 листопада 2018 року); набуття Україною статусу повноправного члена Міжнародного агентства з відновлюваних джерел енергії (IRENA) 24 лютого 2018 року (5 грудня 2017 року Україна приєдналася до Статуту Агентства) [6]. Згідно розпорядження Кабінету Міністрів України було схвалено Енергетичну стратегію України до 2035 року - безпека, енергоефективність, конкурентоспроможність, яка визначає цілі для різних підсекторів енергетики. Документ слугує координаційною основою для сталого інвестування в енергетику та передбачає гармонізацію українського законодавства з низкою директив Свропейського Союзу (СС) [3]. Дана Стратегія базується на цілях, які зможуть покращити рівень забезпечення різних секторів промисловості відновлювальними джерелами енергії, підвищити показники ефективності використання природних ресурсів, очисних споруд та запровадження нових видів діяльності в сучасних умовах господарювання.

Ключові пріоритети розвитку «зеленої економіки» представлені в табл. 2.

Пріоритетною програмою розвитку України у сфері «зеленої економіки» стала програма «Екологізація економіки у країнах Східного партнерства» («ЕaP GREEN») регіональна програма, яка реалізовувалася Європейською економічною комісією ООН, ОЕСР, ЮНЕП та ЮНІДО. Програма охоплювала шість країн Східного партнерства: Вірменію, Азербайджан, Білорусь, Грузію, Республіку Молдову та Україну. Метою програми було сприяння переходу країн Східного партнерства на «зелену» модель розвитку та ведення бізнесу шляхом відокремлення економічного зростання від процесу деградації навколишнього середовища та виснаження ресурсів [1].

«Зелений» сектор економіки дає безліч можливостей для країни за умови його належного фінансування. Для України метою має стати досягнення розумного поєднання економічних та екологічних інтересів, кардинальна структурна зміна промислового виробництва та енергетики у бік забезпечення «зеленого» зростання. Рух України цим шляхом вимагає розробки чіткого плану дій, який повинен відповідати національним інтересам і поділяти погляди бізнес-спільноти, експертного середовища та науковців, а що найголовніше - мати широку підтримку серед населення. 
Таблиця 2 - Ключові пріоритети розвитку «зеленої» економіки

\begin{tabular}{|c|c|}
\hline $\begin{array}{c}\text { Окремі пріоритети розвитку відновлюваної } \\
\text { енергетики }\end{array}$ & \\
\hline 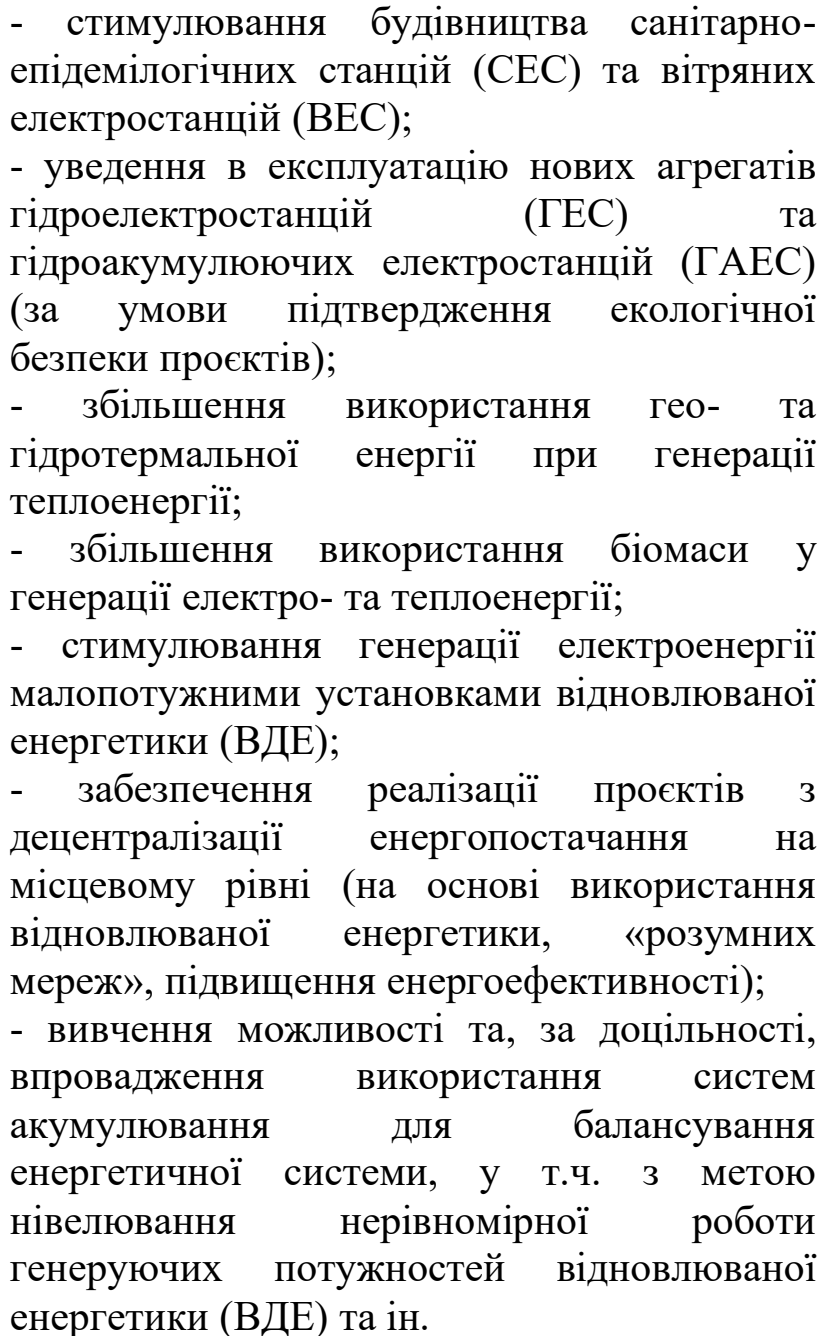 & 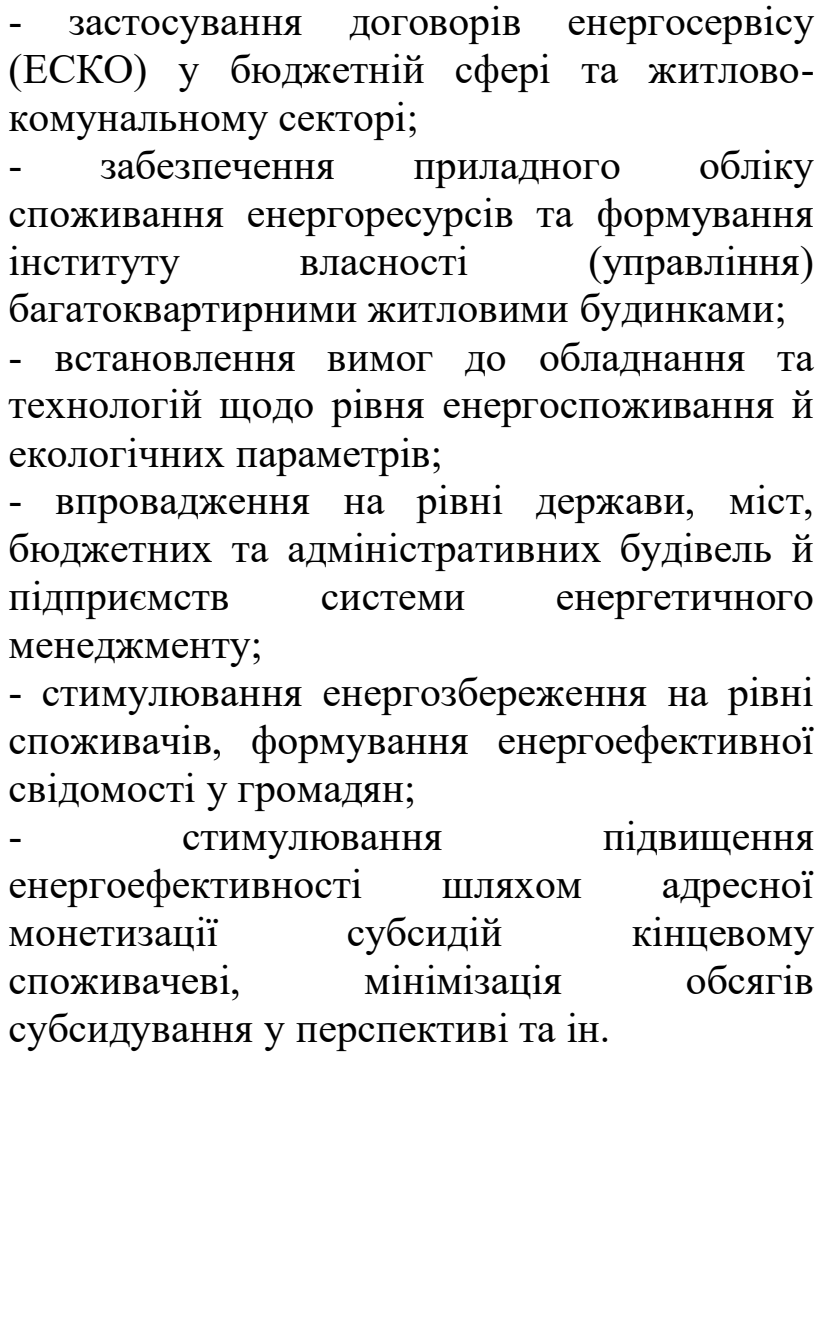 \\
\hline
\end{tabular}

Джерело: систематизовано автором за [7]

Висновки. Стратегія «зеленої» економіки $є$ шляхом до успішного розвитку країни, підвищення іiі конкурентоспроможності та економічної стабільності, шляхом мінімізації ресурсовитрат та забезпечення якісного проживання населення. Заміна стандартних джерел енергії, винайдення нових способів виробництва, екологізація промислових площадок, заохочення випуску та введення в обіг еко товарів та послуг забезпечить перехід держави до нової ери світового господарства шляхом максимізації прибутків та мінімізації шкоди для навколишнього середовища.

За умов наслідування досвіду провідних країн, чіткого державного регулювання та підтримки, якісного забезпечення інвестиціями та чітких законодавчих і правових норм, дана модель переходу та побудови нової економіки може призвести до стрімкого соціальноекономічного поступу України. Зважаючи на світовий досвід, ефективне та раціональне використання ресурсів стимулюватиме розвиток виробництва, розробку нових методик та покращення загального стану економіки. 


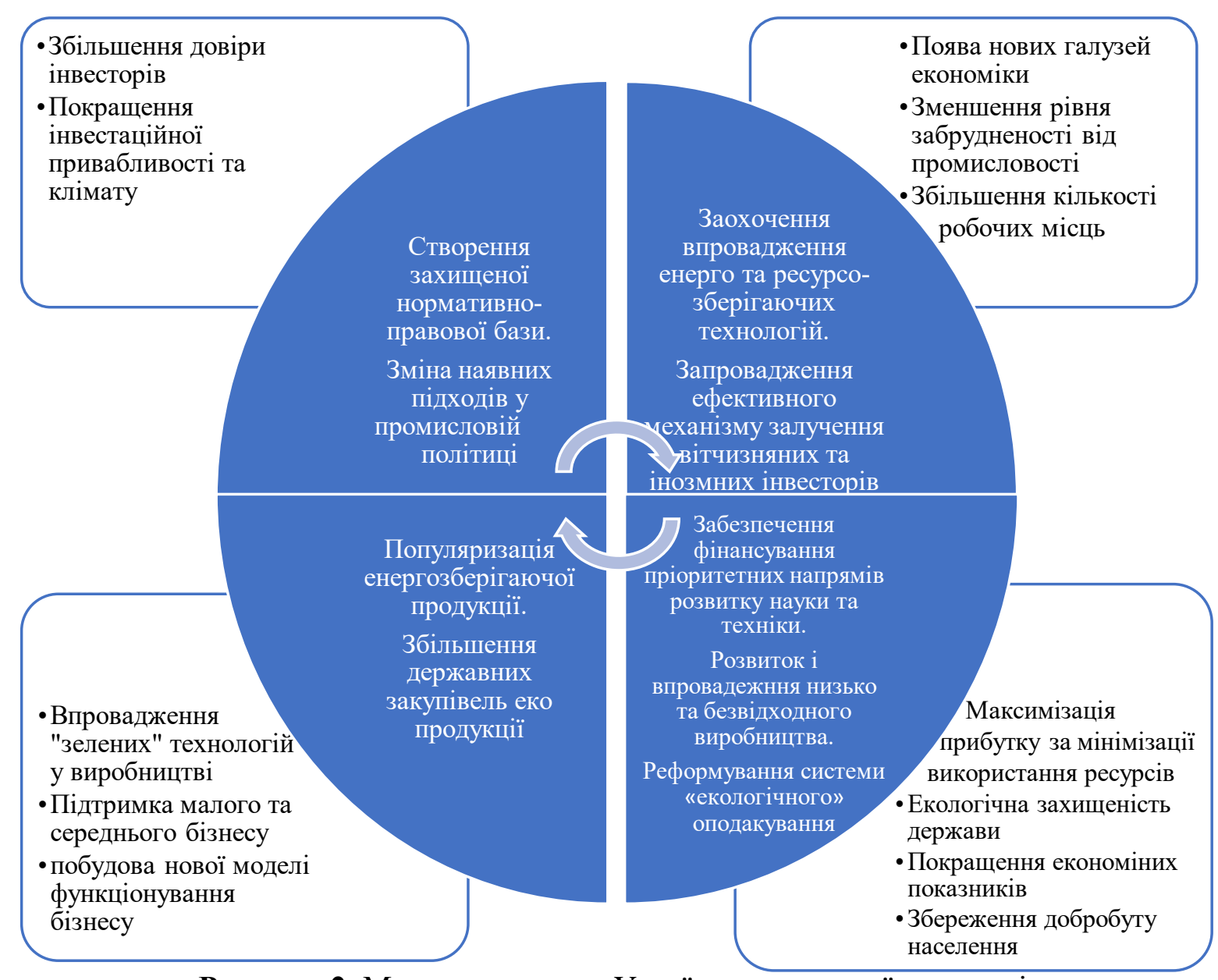

Рисунок 2. Модель переходу України до «зеленої» економіки

Джерело: розроблено автором

Згідно $з$ деклараціями міжнародних організацій у найближчі 10 років світ повинен перейти до нової ери, яка буде супроводжуватися екологізацією виробництва, застосуванням ресурсозберігаючих технологій та заміною сучасних джерел енергії на користь нових, поновлюваних. Тому орієнтація України на «озеленення» економіки $€$ одним із пріоритетних напрямків розвитку держави у напрямку іiї сталого розвитку.

\section{СПИСОК ВИКОРИСТАНИХ ДЖЕРЕЛ}

1. Правовые основы развития зеленой экономики в странах-членах организации Черноморского экономического сотрудничества. Региональный обзор и диалог о системах и перспективах. Совместный проект ЧЭС-ГИЦ. 2012. 8 с.

2. Пан Ги Мун: для «перехода от коричневой к зеленой экономике» нужны триллионы долларов инвестиций. Центр новостей OOH. URL: un.org/russian/news/story.asp?newsID=20983\#.VSmFk9ysWDE (дата звернення: 15.03.2021)

3. Раков И.Д. На пути к зеленой экономике: опыт Италии и Франции. Международный журнал прикладных и фундаментальных исследований. 2018. № 11-2. С. 389-397. URL: https://applied-research.ru/ru/ article/view?id=12511 (дата звернення: 15.03.2021)

4. The Global Green Economy Index. Dual Citizen. 2018. URL: https://dualcitizeninc.com/global-green-economy-index/ (дата звернення: 19.03.2021) 
5. Буркинський Б.В., Галушкіна Т.П., Рутов В.С. «Зелена» стратегія розвитку регіону: монографія. За науковою редакцією Б.В. Буркинського, Т.П. Галушкіної. ІПРЕЕД НАН України. Саки: ПП «Фенікс», 2018. С. 18-35

6. Про схвалення Енергетичної стратегії України на період до 2035 року «Безпека, енергоефективність, конкурентоспроможність»: Розпорядження Кабінету Міністрів України №605 від 18 серпня 2017 p. Урядовий портал. URL: https://www.kmu.gov.ua/ua/npas/250250456 (дата звернення: 15.03.2021)

\section{REFERENCES}

1. Legal framework for the development of a green economy in the member countries of the organization of the Black Sea Economic Cooperation. Regional overview and dialogue on systems and perspectives (2012) (Joint project BSEC-GIC)), 8 p.

2. Pearce, D., Markandya, A., Barbier B. (1989). Blueprint for a Green economy. London: Earthscan, $192 \mathrm{p}$.

3. Rakov, I. (2018). Towards a Green Economy: Experiences from Italy and France. International Journal of Applied and Basic Research. No. 11-2. P. 389-397. URL: https://appliedresearch.ru/ru/article / view? $\mathrm{Id}=12511$

4. The Global Green Economy Index. Dual Citizen. 2018. URL: https://dualcitizeninc.com/global-green-economy-index/

5. Burkinsky, B., Galushkina, T., Rutov, V., (2018) «Green» strategy for the development of the region: a monograph. According to the scientific edition of B., Burkinsky, T., Galushkina. IPREED NAS of Ukraine. Saki: PE «Phoenix». P. 18-35.

6. Order of the Cabinet of Ministers of Ukraine «On approval of the Energy Strategy of Ukraine for the period up to 2035». Security, energy efficiency, competitiveness. №605. August 18, 2017. Government portal. URL: https://www.kmu.gov.ua/en/npas/250250456

Атаманчук 3. А., кандидат экономических наук, доцент кафедры международных экономических отношений, Донецкий национальный университет имени Васыля Стуса, Украина

Неголюк Ю. В., Донецкий национальный университет имени Васыля Стуса, Украина

\section{ИНВЕСТИЦИОННОЕ ОБЕСПЕЧЕНИЕ «ЗЕЛЕНОЙ» ЭКОНОМИКИ КАК ПРИОРИТЕТНОЕ НАПРАВЛЕНИЕ РАЗВИТИЯ ГОСУДАРСТВА НА ПРИНЦИПАХ УСТОЙЧИВОГО РАЗВИТИЯ}

Определены ключевые приоритеты развития «зеленой» экономики; изучено состояние инвестиционного обеспечения «зеленого» сектора в Украине и мире, мировой опыт привлечения «зеленых» технологий в экономику; обоснованно препятствия, сдерживающие увеличение инвестирования в «зеленый» сектор экономики Украины и ключевые приоритеты развития сектора на основе соответствующих программ; сформированы дальнейшие ориентиры развития «зеленой» экономики путем привлечения инвестиций на принципах устойчивого производства и потребления, эффективного использования ресурсов, а также содействие деятельности бизнеса способом ресурсо- и энергоэффективного, экологически безопасного производства. Предложена модель перехода Украины к «зеленой» экономики; обосновано, что в условиях подражания опыта ведущих стран, четкого государственного регулирования и поддержки, качественного обеспечения инвестициями и четких законодательных и правовых норм данная модель перехода и построения новой экономики может привести к стремительному социальноэкономическому развитию Украины. 
Atamanchuk Z., PhD, Associate Professor, International Economic Relations Department, Vasyl' Stus Donetsk National University, Ukraine

Negolyuk Y., Vasyl Stus Donetsk National University, Ukraine

\section{INVESTMENT PROVISION OF «GREEN» ECONOMY AS A PRIORITY DIRECTION \\ OF STATE DEVELOPMENT ON THE BASIS OF SUSTAINABLE DEVELOPMENT}

The key priorities for the development of «green» economy are determined. The state of investment support «green» sector in Ukraine and in the world, the world experience of attracting «green» technologies in the economy has been studied. The obstacles that restrain the increase of investment in the "green» sector of Ukraine's economy and key priorities for the development of the sector based on relevant programs are substantiated. Further benchmarks for the development of «green» economy by attracting investments on the basis of sustainable production and consumption, efficient resources using, as well as promoting business activities in the way of resource and energy-efficient, ecologically safe production are formed. The model of transition of Ukraine to the "green» economy is proposed. It is substantiated that in the conditions of imitation of the experience of leading countries, clear state regulation and support, quality support of investments and clear legislative and legal norms, this model of transition and construction of a new economy can lead to a rapid socio-economic progress of Ukraine. 